\title{
Pink urine as an inkling for a diagnostic dilemma: acute hepatic porphyria
}

\author{
Sufyan Ibrahim (10,1'Aditi Rao (1), ${ }^{1}$ Revathi P Shenoy (i) ${ }^{2}$
}

${ }^{1}$ Kasturba Medical College,

Manipal, Udupi, Karnataka, India ${ }^{2}$ Biochemistry, Kasturba Medical College, Manipal, Udupi,

Karnataka, India

\section{Correspondence to}

Dr Sufyan Ibrahim;

sufyan.ibrahim2@gmail.com

Accepted 24 August 2021
Check for updates

(C) BMJ Publishing Group Limited 2021. No commercial re-use. See rights and permissions. Published by BMJ.

To cite: Ibrahim S, Rao A, Shenoy RP. BMJ Case

Rep 2021;14:e244420.

doi:10.1136/bcr-2021-

244420

\section{DESCRIPTION}

A 23-year-old woman, with 6-week-old intrauterine gestation, presented with severe diffuse abdominal pain of 3 days duration which was intermittent and crampy in nature associated with generalised weakness of all limbs. There was no history of bleeding per-vagina, fever, rashes, diarrhoea, constipation, vomiting, icterus or bleeding diathesis, or history of similar reports in the family. Her vitals were stable. Mild pallor was elicited in bilateral palpebral conjunctiva. Diffuse guarding of abdomen without rigidity or tenderness, with no abdominal distension, organomegaly or excess free-fluid noted on abdominal examination. Regular bowel sounds were present. All other systemic examination was normal. Laboratory analysis revealed haemoglobin of $116 \mathrm{~g} / \mathrm{L}$ (normal: $120-150 \mathrm{~g} / \mathrm{L}$ ) and serum sodium of $118 \mathrm{mmol} / \mathrm{L}$ (normal: $136-145 \mathrm{mmol} / \mathrm{L}$ ). Liver and renal function tests, blood cultures, coagulation profile and lipid profile were normal. Ultrasound of abdomen was only suggestive of intrauterine gestational sac of $6 \mathrm{~mm}$ with no other structural pathology. The urine appeared fluorescent pink when examined under ultraviolet illumination (figure 1). Expedited urine analysis was strongly positive for urine porphobilinogen. A diagnosis of acute hepatic porphyria (AHP) was established.

Acute attacks of AHP are predominantly $(80 \%-$ $90 \%$ of the cases) seen in women of reproductive age group. ${ }^{1}$ AHP does not manifest with cutaneous symptoms such as skin bullous lesions, pushing the suspicion of porphyria further away. ${ }^{2}$ Intriguingly in AHP, symptoms of the disease in the same patient during different episodes and in different patients with the same porphyria subtype are different. ${ }^{3}$ Our patient, a young woman, presented with nonspecific abdominal pain and generalised weakness in

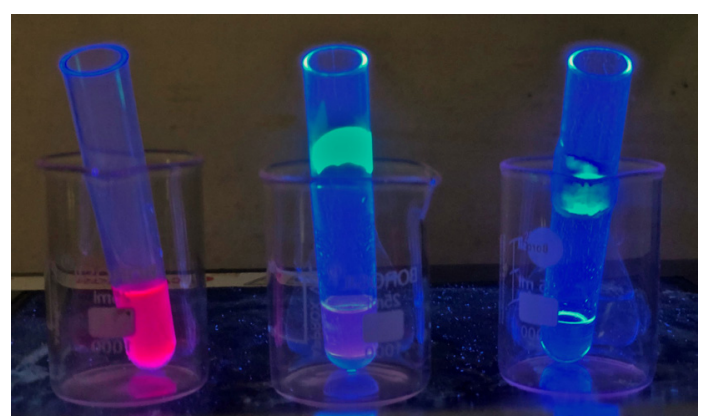

Figure 1 Fluorescent pink colour discolouration of the urine under ultraviolet light examination in acute hepatic porphyria due to oxidation of porphobilinogen into porphobilin, which reduces once acute attack settles down. limbs. Moreover, her $\beta$-human chorionic gonadotropin was elevated indicative of pregnancy, thereby welcoming many obstetric differential diagnoses for her presentation like ruptured ectopic gestation, early pregnancy loss or molar pregnancy, apart from the regular causes for acute abdomen. After ruling them out by a transabdominal ultrasound, porphyria was considered as one of the potential differential diagnoses for her abdominal pain.

Urinary porphobilinogen testing is the singlemost commonly used investigation for establishing the diagnosis of AHP. Although qualitative tests yield rapid results, they are subject to falsepositivity. ${ }^{1}$ On the contrary, quantitative tests are confirmatory, but have greater turnaround time and are costlier. ${ }^{1}$ Genetic testing can differentiate the subtypes of porphyria, but its role in diagnosis is remote owing to its cost and availability. Simple, efficient, time-effective and cost-effective methods like first-line examination of urine sample under ultraviolet light have a potential role in investigating these rare diagnostic dilemmas under appropriate clinical suspicion. It has a high specificity, especially when clinical signs are compatible with an acute porphyria attack. This test safely prevents the larger proportion of non-porphyria cases from being subjected to unnecessary assays that increase

\section{Patient's perspective}

I was mentally at peace knowing my diagnosis. had similar episodes before, but of lesser intensity and had been ignoring them. I believe that I am currently doing well and am able to carry out my tasks normally. I am also aware that a few precipitating factors could lead to acute attacks and shall try to avoid them.

\section{Learning points}

Variable, non-specific presentation makes acute hepatic porphyria a diagnostic challenge, warranting a good clinical acumen.

- Clinical cues like urine turning dark on standing are overlooked due to inadequate patientinteraction, thus underscoring the importance of a dedicated bed-side workup.

- Simple method like urine examination under ultraviolet light should be used to accelerate the diagnosis, particularly in peripheral healthcare settings where timely urine porphyrin estimation is not feasible. 
both healthcare expenses and time. At the same time, it expedites the diagnosis by narrowing down only a select group of cases that have positive result in ultraviolet light examination to be subjected to further assays. Delayed recognition and treatment of AHP has both acute life-threatening complications and long-term repercussions due to recurrent attacks which can only be prevented by arriving at the diagnosis early. Hence, it strikes a safe balance between the two and abates the excessive dependence on time-consuming, less-accessible and costlier porphyrin assays.

Twitter Sufyan Ibrahim @Ornate_Brute and Aditi Rao @adroit_foetus

Contributors SI and RPS: planning; SI and AR: conduct and manuscript writing; AR and RPS: reporting; SI, AR and RPS: conception and design; RPS: methodology and manuscript review.
Funding The authors have not declared a specific grant for this research from any funding agency in the public, commercial or not-for-profit sectors.

Competing interests None declared.

Patient consent for publication Obtained.

Provenance and peer review Not commissioned; externally peer reviewed.

\section{ORCID iDs}

Sufyan Ibrahim http://orcid.org/0000-0001-9127-2738

Aditi Rao http://orcid.org/0000-0003-2267-9352

Revathi P Shenoy http://orcid.org/0000-0002-8475-4824

\section{REFERENCES}

1 Bissell DM, Anderson KE, Bonkovsky HL. Porphyria. N Engl J Med Overseas Ed 2017:377:862-72.

2 Edel Y, Mamet R. Porphyria: what is it and who should be evaluated? Rambam Maimonides Med J 2018:9:e013.

3 Vakili R, Armanpoor P. Acute intermittent porphyria: a diagnostic challenge. Iran $J$ Pediatr 2016:26:e5238.

Copyright 2021 BMJ Publishing Group. All rights reserved. For permission to reuse any of this content visit

https://www.bmj.com/company/products-services/rights-and-licensing/permissions/

BMJ Case Report Fellows may re-use this article for personal use and teaching without any further permission.

Become a Fellow of BMJ Case Reports today and you can:

- Submit as many cases as you like

- Enjoy fast sympathetic peer review and rapid publication of accepted articles

- Access all the published articles

Re-use any of the published material for personal use and teaching without further permission

Customer Service

If you have any further queries about your subscription, please contact our customer services team on +44 (0) 2071111105 or via email at support@bmj.com.

Visit casereports.bmj.com for more articles like this and to become a Fellow 